\title{
Strategies of Post-entry Foreign Expansion: Speed-up or Slow-down?
}

\author{
Bau-Jung Chang ${ }^{1}$ \\ ${ }^{1}$ Department of Business Administration, Feng Chia University, Taichung, Taiwan \\ Correspondence: Bau-Jung Chang, Department of Business Administration, Feng Chia University, Taichung, \\ Taiwan. Tel: 886-4-2451-7250 Ext. 4614. E-mail: changbj@fcu.edu.tw
}

$\begin{array}{ll}\text { Received: April 25, } 2012 & \text { Accepted: May 21, } 2012 \quad \text { Online Published: July 10, } 2012 \\ \text { doi:10.5539/ibr.v5n8p123 } & \text { URL: http://dx.doi.org/10.5539/ibr.v5n8p123 }\end{array}$

\begin{abstract}
This study explores the antecedents of the speed of post-entry foreign expansion in a host country. Employing competitive dynamics and organizational learning theories, the study examines the effect of competition, country-specific experience, and general international business experience on the time span between two consecutive entries made by a focal firm in a host country. The study analyses these factors in a dynamic context using a sample of 94 Taiwanese manufacturers in electronic industry with 190 entries between 1991 and 2004. The results show a firm makes faster post-entry expansion when a large number of firms in the same industry sector invest in that host country as a result of competition. However, cumulative host-country and general international business experience result in slower subsequent reinvestment. The findings not only contribute to the literature on competition, organizational learning, and international business, but also enrich our understanding on the evolutionary path of international expansion.
\end{abstract}

Keywords: competitive dynamics, organizational learning theory, post-entry expansion

\section{Introduction}

In the management research, time has always been an important component of the antecedents of market position, competitive advantage and firm performance, whether time exists as a real phenomenon or is epiphenomenal (Mosakowski \& Earley, 2000). In particular, research of time-based competition (Stalk \& Hout, 1990), the speed in strategic decision making (Eisenhardt, 1990), and the timing of competitive responses (Chen, 1996; Chen \& MacMillan, 1992; Chen, Smith \& Grimm, 1992) in strategic management field, have regarded time as an important strategic outcome variable related to the impact of firm performance.

In research on international business, timing of entry (Delios \& Makino, 2003; Isobe, Makino \& Montgomery, 2000), decisions of entry mode (Chang \& Rosenzweig, 2001), as well as location choices (Chang \& Park, 2005; Henisz \& Delios, 2001; Hennart \& Park, 1994), time has already been taken into consideration in studies, and the emphasis was mostly on the discussion of initial entry.

However, the speed of post-entry expansion, in terms of the time span between a firm's first entry and subsequent entries in an international market, has attracted little attention in research. Over time, the strategies of post-entry expansion might change and in turn affect how firms rebuild their competitiveness and take advantage of available opportunities in the host countries. To explore the speed of post-entry expansion can not only enrich our knowledge of the strategic arrangements of a firm in a specific international market, but also trace the evolutionary path and the heterogeneity among firms within the same industrial sector. This challenge is beyond the issue of initial entry and serves as the center of this paper.

Other research streams, found in economics and strategic management literatures, have produced abundant studies on the antecedents of market entries and the influences on performance. The traditional static analysis of competition in industrial organizational economics (Bain, J. S., 1956) has turned to dynamic analysis in the current competitive environment (Chen, 1996; Chen \& MacMillan, 1992; Chen et al., 1992; D’Aveni, 1994; Gimeno \& Woo, 1996; Tirole, 1988). The interdependence among firms results in the consideration of rivals' actions when a firm acts.

A number of researchers note the sequential expansion drawing on an evolutionary point of view (Chang, 1995; Chang et al., 2005; Chang et al., 2001; Guillen, 2003). Several authors also highlighted the dynamics of international expansion, such as Acedo and Jones (2007), Morgan-Thomas and Jones (2009), Musteen, Francis, and Datta (2010), and Prashantham and Young (2011). However, in international expansion strategies, such as 
knowledge accumulation and capability building through sequential investment activities, the investigation on the speed of post-entry expansion rarely caught the attention of researchers.

Hence, this study explores the antecedents of the speed of post-entry expansion in a host country. What factors determine the speed of post-entry foreign expansion of multinational corporations? How faster or how slower may a firm choose to entry a focal market? Drawing on competitive dynamics and learning theory, this paper analyzes the influence of competitive conditions and firm-experience factors on the speed of post-entry expansion. The study examines longitudinal data of 94 Taiwanese firms in eight sectors of electronic industry with 190 entries in China between 1991 and 2004. The result shows that competition among firms, country-specific experience, and general international business experience all affect the speed of post-entry foreign market expansion.

This paper is organized as follows. The first section reviews the existing literatures and develops hypotheses based on the theories. In the second section, the data sources and methodology are described. The next section shows the results, and conclusion and discussion are presented in the final section.

\section{Theory and Hypotheses Development}

\subsection{Competitive Dynamics and Speed of Post-entry Foreign Expansion}

From classical economics to industrial organizational economics, the interdependences among competitors and the consequences of interactions have captured the interest of researchers. In this stream of research, the scholars from Harvard school such as Bain, Mason, and the following significant researchers, Cave and Porter, all emphasize the relationship among structure-conduct-performance (Bain, 1956; Caves \& Porter, 1977; Mason, 1957). They propose that firms' behavior is influenced by industrial structure, and firms' behavior would change the original structure and relative positions within firms.

The static competition among firms in classical economics, on the other hand, turns to dynamic competition analysis through techniques of game theory and action/response dyad in contemporary strategic management research (Saloner, 1991; Schmalensee, 1988; Chen \& Miller, 1994). This stream of research focuses on the analysis of the action and counter-action among rivals and investigates the antecedents of such interdependence, the attributes of rivals and counter-rivals, and the effects on strategic choices and performance (Chen, 1996; Chen \& MacMillan, 1992; Chen et al., 1992; Smith, Grimm, Gannon \& Chen, 1991). The analysis among rivals in the dynamic environment is centered on strategic and tactic actions which contains pricing strategies, new product offering, mergers and acquisitions, market entry, etc. (D’Aveni, 1994; Smith et al., 1991).

Chen (1996) proposes that the firms recognize and perceive the interdependence with each other as resulting from the market commonality and resources similarity. Over time, the interdependence makes the actions of these firms follow a similar pattern, and thus the rivals in an industry or categorized sector seem to engage in collective sense-making (Porac \& Rosa, 1996).

In the international business literature, firms often make foreign expansions as a result of seeking resources, markets, efficiency, or strategic assets (Dunning, 1993). Efficiency and market seeking are the main drivers of competition because the two factors directly influence firms' value (market) and cost (efficiency), and they determine firms' profit indirectly.

On the one hand, based on the approach of efficiency seeking, firms make international expansion in a specific country, which implies there are relatively low-wage labors or low-price materials. The firms with foreign expansions in a specific country often obtain comparative advantages, while those without entries or with few entries would face relative disadvantages. Consequently, once the firms perceive the number of subsidiaries established in the specific host country by other firms in the same industry increase, they would probably make faster post-entry expansion in order to catch up with their rivals and to sustain their own competitiveness.

On the other hand, preemption is one of the main strategies that firms act for expanding their market domain. Firms set up more subsidiaries to enlarge their capacity and resources in order to discover new market opportunities in the host country. For this reason, when a firm observes more and more firms in the same industry have established subsidiaries in a host country, it is likely to quickly reinvest in the same country for acquiring the market opportunities. Furthermore, the quick reinvestment could avoid gaining from preemption by other firms. Hence, the study hypothesizes as below:

Hypothesis 1: The more firms in the same industry make entries in the host country, the faster a focal firm reinvests in that country.

\subsection{Experience, Capability Building, and Speed of Post-entry Foreign Expansion}

Organizational learning is routines-based, history-dependent, and target-oriented (Levitt \& March, 1988). 
Organizational routines are repeatedly invoked and socially constructed programs of action that embody the knowledge, capabilities, belief, values, and memory of the organization and its decision makers (Nelson \& Winter, 1982). Choice and actions encoded in routines are more likely to be attended to and accepted by organizational members and decision makers.

Learning research includes using dichotomous typologies such as lower-level learning versus higher-level learning (Fiol \& Lyles, 1985), double-loop learning versus single-loop learning (Argyris \& Schon, 1978), and exploitation learning versus conceptual learning (Kim, 1993). To understand more complete organizational learning, Huber (1991) elaborates on four constructs: knowledge acquisition, information distribution, information interpretation, and organizational memory, linked to organizational learning. According to the behavior perspective, an entity learns through its processing of information, and may make potential behavior changed (Huber, 1991). The highlight of organizational learning is about how the information and knowledge transform and share within a firm, and how the behavior change.

Experience of multinational corporations in the strategic decision-making has been noted by a number of international business researchers. Both country specific experience in a particular host country and general international experience which obtained by global operations could impact the strategic choices on MNCs (Padmanabhan \& Cho, 1999). Learning through direct experience makes the accumulated experience stored in organizational memory, and promotes local search with organizations (Levitt et al., 1988).

Learning by doing is to measure changes in productivity or the rewards to productivity which accrue from experience (Foster \& Rosenzweig, 1995). The learning curve literature in economics points out advantages in accumulating experience and know-how. The increasing cumulative production makes the cost per unit decline. As the firms get more experienced at a particular task, they usually become more efficient at them. Chang (1995) has noted that intrinsic disadvantages in a foreign country may substantially diminish due to their capability improvement through accumulating knowledge. The operating experience in a specific host country accumulates firms' knowledge regarding the economic and political environment, market size, and competition conditions in that market and thus helps firms easily acquire the operation skills from existing routines when they decide to make subsequent investments. The exploration decreases the search cost and makes faster post-entry expansion possible.

A few researchers in international business have pointed out that foreign direct investment ought to be a sequential process (Kogut, 1983; Kogut \& Kulatilaka, 1994). Multinational corporations' initial investments provide outposts from which to learn about the environment (Shaver, Mitchell \& Yeung, 1997). Thus, the initial investment can be regarded as options for making appropriate expansion in a local environment. Some empirical findings also show that great host-country experience promotes firms to develop multinational expansion capabilities by reducing the liabilities of foreignness in the host market (Chang, 1995; Chang et al., 2001; Kogut, 1983).

Previous studies investigate host-country experience and international expansion experience through sequential investments and their impact on the strategies of subsequence of foreign expansions such as choice of entry mode or ownership structure (Padmanabhan et al., 1999). This study posits that the time span of post-entry expansion will be shorter when firms have more host country experience according to the reasoning above. Once it is assured of the market potential from previous experiences in the host country and it decides to make further investment, entry will occur faster. In addition, the firms may also acquire operating knowledge in multiple countries. The firms with international experience can generate leverage knowledge acquired in different countries and develop a set of best practices based on their collective learning. Once the firms decide to enter a host country, the cumulative international business experience would reduce the time needed for subsidiary establishment, and therefore make subsequent entries faster. For these reasons, this paper hypothesizes as follows:

Hypothesis 2: The more host country experience a focal firm has, the faster the focal firm reinvests in that country.

Hypothesis 3: The more international experience a focal firm has, the faster the focal firm reinvests in that country.

\section{Methods}

\subsection{Sample and Data Sources}

To test the hypotheses, the study examines foreign investment decisions made by Taiwanese electronic manufacturers that invest in China. There are several sectors in the electronic industry. The sectors are classified by the Taiwan Economic Journal (TEJ) database according to product attributes. The firms in the same sector 
have similar products and customers and face the same technological and competitive environment that defines them within the same sector as the reference group. Taiwanese firms in the electronic industry possess the greatest market shares in the world. For example, the worldwide market shares of motherboard and notebook PC are $98.4 \%$ and $82.5 \%$ separately in 2005 . Thus it is reasonable to infer that global competition is not essential for Taiwanese electronic firms and the reference group could be restricted to the domestic country.

The sample of this study contains information on the electronic firms in the first section of the Taiwan stock market. The firm-specific information was obtained from the TEJ database, which includes finance information of firms in the stock market. However, some categories and firms were not allowed by the Taiwanese government to invest in China, such as the semiconductor and telecommunication firms, and thus these firms were excluded.

The data on Taiwanese firms' investment in China were obtained from the Investment Commission. The data include parent companies, subsidiaries, locations, and the dates when the investments obtained authorization. In order to investigate the speed of post-entry foreign expansion in a given country, the dataset is limited to firms that had at least two entries in China from 1991 to 2004. Finally the sample of firms included 94 Taiwan electronic manufacturers in eight sectors, and these firms totally made 190 entries to China during the study period. The data included 94 firms over 1991-2004, allowing the use of longitudinal data analysis techniques. The results of the Hausman specification test suggested that a fixed-effect model was appropriate.

\subsection{Variables and Measurements}

\subsubsection{Dependent Variable}

Speed of Expansion. I coded a variable that measures the time span between two consecutive entries made by a firm. The higher the value is, the slower the speed of post-entry expansion is.

\subsubsection{Independent Variables}

The Number of Prior Entrants. The number of prior entrants was calculated as the proportion of firms in the same sector that had previously established a subsidiary in China. This variable was measured at time $\mathrm{t}-1$ of the investment.

Country-specific Experience. Scandinavian school (Johanson \& Wiedersheim-Paul, 1975; Johanson \& Vahlne, 1977) argues that the most important obstacle to internationalization is the lack of knowledge and resources. When firms accumulate their own experience and enhance their knowledge about that country, firms will engage in a higher level of investment activities. In addition, Hennart and Park (1994) found significant support for the experience effect on Japanese firms investing in the United States. In Kogut and Chang's (1996) study, they found that the firms with numerous investments were more likely to invest subsequently. The focal firm's experience was operationalized as the log of the number of subsidiary years of the host country experience at the time of $\mathrm{t}-1$ of investment. Prior to logging the experience variable, one year was added to the sum of the subsidiary years to avoid the indeterminacy of logging zero experience.

General International Business Experience. General international business experience was measured as the logarithm of the cumulative years since a focal firm established its first subsidiary internationally aside from China at the time of $\mathrm{t}-1$ of investment. One year was added to the sum of years to avoid the indeterminacy of logging zero experience prior to logging the international experience variable.

\subsubsection{Control Variables}

Sales. Sales were used as control for firm size and overall access to resources (Gimeno, Hoskisson, Beal \& Wan, 2005). Empirical evidence also shows that larger Japanese semiconductor firms are more likely to engage in investment activities (Kimura, 1989). The firm size was measured by the log of net sales at time t-1 of the investment.

Return on Assets. Performance may encourage firms for international expansion and foreign investments. Besides, a high return on assets might also reflect the presence of valuable intangible assets in technology or organizational routines. As such, assets might induce firms to invest abroad to exploit these assets (Hennart, 1982). Return on assets was measured at time $t-1$ of the investment in order to reflect the financial performance at the firm level.

$R \& D$ Intensity. Technology and marketing know-how are intangible resources which could induce foreign direct investments, not only to generate monopolistic advantages but also to create needs for internalization (Buckley \& Casson, 1976; Hennart, 1982; Hennart et al., 1994). Hennart and Park (1994) also showed that the larger a Japanese firm's R\&D expenditures are, the greater the probability it would manufacture in the United States. The 
measure was calculated by the Research and Development (R\&D) expenditures divided by the total sales at time $\mathrm{t}-1$ of the investment.

Advertising Intensity. The scholars of the internalization theory argue that firms with intermediate products such as R\&D knowledge, product-related and market-related information tend to engage in internalization activities (Buckley et al., 1976). Hence, advertising intensity, like R\&D intensity, should encourage firms to engage in foreign investment activities. The measure was calculated by the advertising expenditures divided by the total sales at time $\mathrm{t}-1$ of the investment.

Table 1 presents the descriptive statistics and the Pearson's correlation coefficients between pairs of explanatory variables. In Table 1, there shows some significant correlations among these variables. To check for the presence of multicollinearity, this paper employs the method of variance inflation factor (VIF). None of the VIF values among the independent variables exceeds 10 , so the potential problem associated with multicollinearity can be ruled out (Neter, Kutner \& Nachtsheim, 1996).

Table 1. Descriptive Statistics and Pearson Correlations

\begin{tabular}{|c|c|c|c|c|c|c|c|c|c|c|c|}
\hline & Variable & Mean & s.d. & $\mathbf{N}$ & 1 & 2 & 3 & 4 & 5 & 6 & 7 \\
\hline 1. & Speed of Expansion & 2.274 & 1.739 & 190 & & & & & & & \\
\hline 2. & Net Sales ${ }^{\mathrm{a}}$ & 6.800 & 0.644 & 190 & -0.10 & & & & & & \\
\hline 3. & Return on Assets & 12.240 & 8.207 & 190 & $-0.18^{*}$ & $-0.23^{*}$ & & & & & \\
\hline 4. & R\&D Intensity & 0.030 & 0.027 & 188 & 0.08 & $-0.32^{*}$ & 0.06 & & & & \\
\hline 5. & Advertising Intensity & 0.002 & 0.003 & 187 & -0.08 & -0.13 & 0.09 & $0.44^{*}$ & & & \\
\hline 6. & Proportion of Previous Entry & 0.515 & 0.236 & 190 & -0.04 & $0.16^{*}$ & $-0.16^{*}$ & $-0.16^{*}$ & $-0.29^{*}$ & & \\
\hline 7. & Country-specific Experience $^{\mathrm{a}}$ & 0.832 & 0.362 & 190 & $0.20^{*}$ & $0.29^{*}$ & $-0.23^{*}$ & 0.01 & -0.07 & $0.26^{*}$ & \\
\hline 8. & General International Experience $^{\mathrm{a}}$ & 0.701 & 0.453 & 190 & 0.09 & $0.20^{*}$ & $-0.20^{*}$ & -0.02 & $-0.22^{*}$ & $0.23^{*}$ & $0.18^{*}$ \\
\hline
\end{tabular}

\section{Results}

The results of the fixed effect model are shown in Table 2. The table includes control variables and hypothesized variables.

Table 2. Fixed Effect Model in Speed of Post-entry Expansion ${ }^{\mathrm{a}}$

\begin{tabular}{lll}
\hline Variable & Model 1 & Model 2 \\
\hline Net Sales $^{\mathrm{b}}$ & -0.035 & -0.356 \\
& $(0.71)$ & $(1.07)$ \\
Return on Assets & -0.008 & -0.028 \\
& $(0.03)$ & $(0.03)$ \\
R\&D Intensity & -5.933 & -21.016 \\
& $(18.08)$ & $(18.54)$ \\
Advertising Intensity & -120.784 & -126.469 \\
& $(94.38)$ & $(89.26)$ \\
Proportion of Previous Entry & & $-5.780^{* * *}$ \\
& & $(1.67)$ \\
Country-specific Experience ${ }^{\mathrm{b}}$ & & $1.763^{+}$ \\
& & $(0.99)$ \\
General International Experience ${ }^{\mathrm{b}}$ & & $5.239^{* *}$ \\
& & $(1.99)$ \\
Constant & 3.049 & 3.769 \\
& $(5.10)$ & $(6.77)$ \\
$\mathrm{N}$ & 187 & 187 \\
F-test & 0.56 & $2.61^{*}$ \\
\hline
\end{tabular}

Model 1 contains only control variables. The control variables are used to relate to other factors, which may encourage the firms' foreign investments and accelerate the speed of post-entry expansion. Model 1 indicates that large firms, the firms with high returns on assets, high R\&D intensity and advertising intensity are more likely to make post-entry expansion faster, but these influences do not reach statistical significance.

Hypothesized variables are included in Model 2. Hypothesis 1 predicts that the more firms in the same home 
country industry that make entries in the host country, the faster a focal firm will reinvest in that market. The coefficient of proportion of prior entries is negative and significant $(\mathrm{p}<0.001)$, so Hypothesis 1 is supported.

Hypothesis 2 posits that the more operating experience of a focal firm in the host country, the more likely for a firm to make post-entry expansion faster. The results show that the coefficient of the firms' own experience is positive and significant $(\mathrm{p}<0.1)$ in Model 2, which is opposite to expectation. Therefore, Hypothesis 2 is not supported.

Hypothesis 3 proposes that a focal firm may make faster post-entry expansion in a given country when a focal firm has more general international operating experience. The coefficient of the firms' international experience is positive and significant $(\mathrm{p}<0.01)$, and is also opposite to expectation. The result therefore does not support Hypothesis 3.

\section{Discussion and Conclusion}

This study aims to explore the influences of competition, country specific, and general international business experience on the speed of post-entry foreign expansions. Drawing on competitive dynamics, organizational learning, and international business theories, the study proposes that the firm may make faster subsequent entries related to competition conditions, but cumulative experience in the host country and multiple international markets may induce the firm to reinvest slower in the host country.

Hypothesis 1 predicts that the speed of subsequent investments in a host country is negatively related to the number of firms in the same industry that have entered in the host country. The higher value of speed means slower expansion. The findings strongly support this prediction and confirmed that the post-entry expansion is determined by competition reactions. The perceived interdependence causes a firm's quick response to rivals' actions and makes faster subsequent entries. The result is consistent with the theories of economics and competitive dynamics (Chen \& MacMillan, 1992). Organizations generally respond to challenges in their market by making competitive counterattacks (Chen et al., 1994). Awareness of mutual interdependence increases the likelihood that a firm will respond to neutralize the effect of a rival's moves and deter further attacks (Chen et al., 1994). Moreover, the paper contributes to perspective of competitive dynamics because it opens the sight from competitive interactions to the evolution of a focal firm's foreign expansion due to interdependence of firms.

Hypotheses 2 and 3 investigate the influence of country-specific and general international business experience on the speed of post-entry expansion respectively. The findings show that more country-specific and general international business experience will slow down focal firm's sequential entry in the host country. Although the findings are opposite to expectation, the results inform further research. The internalization of knowledge and capabilities will need a long time for incubation, rather than like external shock, such as competitive pressure, needs to response immediately. Researcher in organizational learning theory has pointed out that organization is an adaptive system and path dependence (Levitt \& March, 1988). However, how fast will be an organization change is absence in relative literature. This paper moves forward to a new viewpoint of organizational learning and also contributes to this stream of research.

Besides, the risk taking attitude might influence the speed of subsequent entries in a given host country. According to prospect theory (Kahneman \& Tversky, 1979), firms with abundant experience in the host country and international markets can be regarded as a gain condition relative to status quo. The loss aversion attitude may discourage firms from faster subsequent entries. On the other hand, firms with deficient experience in the markets face a loss condition relative to status quo. Thus the risk seeking managers are encouraged to make faster entries in the post-entry expansion.

In summary, this study enhances the understanding of competitive dynamics, organizational learning, and international expansion theories. Our findings strongly support the prediction of competition and expand its empirical context onto post-entry expansion strategies.

Nonetheless, this study has several limitations. First, only the quantity of experience and not the quality of experience was measured. The feedback from previous own-firm experience is an essential concept and is used to select among alternatives in organizational learning (Levitt et al., 1988; March \& Olsen, 1975). Second, this study just focuses on foreign entry of the electronic firms in China. Future research could extend this model across industries and compare the different investment behaviors among firms, thus making it possible to obtain a more comprehensive understanding about international expansion behavior.

\section{References}

Acedo, F. J., \& Jones, M. V. (2007). Speed of internationalization and entrepreneurial cognition: Insights and a comparison between international new ventures, exporters and domestic firms. Journal of World Business, 
42(3), 236-252. http://dx.doi.org/10.1016/j.jwb.2007.04.012

Argyris, C., \& Schon, D. (1978). Organizational Learning. Reading, MA: Addison-Wesley.

Bain, J. S. (1956). Barriers to New Competition. Cambridge, MA: Harvard University Press.

Buckley, P. J., \& Casson, M. (1976). The Future of the Multinational Enterprise. New York: Holmes and Meier Publishers.

Caves, R. E., \& Porter, M. E. (1977). From Entry Barriers to mobility Barriers. Quarterly Journal of Economics, 91, 241-262. http://dx.doi.org/10.2307/1885416

Chang, S. J. (1995). International Expansion Strategy of Japanese Firms: Capability Building through Sequential Entry. Academy of Management Journal, 38(2), 383-407.

Chang, S. J., \& Park, S. (2005). Types of Firms Generating Network Externalities and MNC’s Co-location Decisions. Strategic Management Journal, 26, 595-615. http://dx.doi.org/10.1002/smj.464

Chang, S. J., \& Rosenzweig, P. M. (2001). The choice of entry mode in sequential foreign direct investment. Strategic Management Journal, 22(8), 747-776. http://dx.doi.org/10.1002/smj.168

Chen, M. J. (1996). Competitor Analysis and Interfirm Rivalry: Toward a Theoretical Integration. Academy of Management Review, 21(1), 100-134. http://dx.doi.org/10.5465/AMR.1996.9602161567

Chen, M. J., \& MacMillan, L. C. (1992). Nonresponse and Delayed Response to Competitive Moves: The Roles of Competitor Dependence and Action Irreversibility. Academy of Management Journal, 35(3), 539-570. http://dx.doi.org/10.2307/256486

Chen, M. J., \& Miller, D. (1994). Competitive Attack, Retaliation and Performance: An Expectancy-Valence Framework. Strategic Management Journal, 15(2), 85-102. http://dx.doi.org/10.1002/smj.4250150202

Chen, M. J., Smith, K. G., \& Grimm, C. M. (1992). Action Characteristics as Predictors of Competitive Responses. Management Science, 38(3), 439-455. http://dx.doi.org/10.1287/mnsc.38.3.439

D’Aveni, R. A. (1994). Hypercompetition: Managing the Dynamics of Strategic Maneuvering. New York: Free Press.

Delios, A., \& Makino, S. (2003). Timing of Entry and the Foreign Subsidiary Performance of Japanese Firms. Journal of International Marketing, 11(3), 83-105. http://dx.doi.org/10.1509/jimk.11.3.83.20158

Dunning, J. H. (1993). Multinational Enterprises and Global Economy. New York: Addison Wesley.

Eisenhardt, K. M. (1990). Speed and Strategic Choice: How Managers Accelerate Decision Making. California Management Review, 32(3), 39-54.

Fiol, C. M., \& Lyles, M. A. (1985). Organizational Learning. Academy of Management Review, 10(4), 803-813. http://dx.doi.org/10.5465/AMR.1985.4279103

Foster, A. D., \& Rosenzweig, M. R. (1995). Learning by Doing and Learning from Others: Human Capital and Technical Change in Agriculture. Journal of Political Economy, 103, 1176-1209. http://dx.doi.org/10.1086/601447

Gimeno, J., \& Woo, C. Y. (1996). Hypercompetition in a Multimarket Environment: The Role of Strategic Similarity and Multimarket Contact in Competitive De-escalation. Organization Science, 7(3), 322-341. http://dx.doi.org/10.1287/orsc.7.3.322

Gimeno, J., Hoskisson, R. E., Beal, B. D., \& Wan, W. P. (2005). Explaining the Clustering of International Expansion Moves: A Critical Test in the U.S. Telecommunications Industry. Academy of Management Journal, 48(2), 297-319. http://dx.doi.org/10.5465/AMJ.2005.16928411

Guillen, M. F. (2003). Experience, Imitation, and the Sequence of Foreign Entry: Wholly Owned and Joint-Venture Manufacturing by South Korean Firms and Business Groups in China, 1987-1995. Journal of International Business Studies, 34(2), 185-198.

Henisz, W. J., \& Delios, A. (2001). Uncertainty, Imitation, and Plant Location: Japanese Multinational Corporations, 1990-1996. Administrative Science Quarterly, 46(3), 443-475. http://dx.doi.org/10.2307/3094871

Hennart, J. F. (1982). The Theory of the Multinational Enterprise. Ann Arbor: University of Michigan Press.

Hennart, J. F., \& Park, Y. (1994). Location, Governance, and Strategic Determinants of Japanese Manufacturing Investment in the United States. Strategic Management Journal, 15(6), 419-436. 
http://dx.doi.org/10.1002/smj.4250150602

Huber, G. P. (1991). Organizational Learning: The Contributing Processes and Literatures. Organization Science, 2(1), 88-117. http://dx.doi.org/10.1287/orsc.2.1.88

Isobe, T., Makino, S., \& Montgomery, D. B. (2000). Resource Commitment, Entry Timing, and Market Performance of Foreign Direct Investments in Emerging Economies: The Case of Japanese International Joint Ventures in China. Academy of Management Journal, 43(3), 468-484. http://dx.doi.org/10.2307/1556405

Johanson, J., \& Vahlne, J. E. (1977). The Internationalization Process of the Firm - A Model of Knowledge Development and Increasing Foreign Market Commitments. Journal of International Business Studies, 8(1), 23-32. http://dx.doi.org/10.1057/palgrave.jibs.8490676

Johanson, J., \& Wiedersheim-Paul, F. (1975). The International of the Firm- Four Swedish Cases. Journal of Management Studies, 12(3), 305-322. http://dx.doi.org/10.1111/j.1467-6486.1975.tb00514.x

Kahneman, D., \& Tversky, A. (1979). Prospect Theory: An Analysis of Decisions under Risk. Econometrica, 47, 313-327. http://dx.doi.org/10.2307/1914185

Kim, D. (1993). The Link between Individual and Organizational Learning. Sloan Management Review, Fall, 37-59.

Kimura, Y. (1989). Firm-specific Strategic Advantages and Foreign Direct Investment Behavior of Firms: The Case of Japanese Semiconductor Firms. Journal of International Business Studies, 20, 296-314. http://dx.doi.org/10.1057/palgrave.jibs.8490360

Kogut, B. (1983). Foreign Direct Investment as a Sequential Process. In C. P. Kindleberger (Ed.), The Multinational Corporation in the 1980s (pp. 35-56). Cambridge, MA: MIT Press.

Kogut, B., \& Kulatilaka, N. (1994). Operating Flexibility, Global Manufacturing, and the Option Value of a Multinaitonal network. Management Science, 40, 123-139. http://dx.doi.org/10.1287/mnsc.40.1.123

Levitt, B., \& March, J. G. (1988). Organizational Learning. Annual Review of Sociology, 14, 319-340. http://dx.doi.org/10.1146/annurev.so.14.080188.001535

March, J. G., \& Olsen, J. P. (1975). The Uncertainty of the Past: Organizational Learning under Ambiguity. European Journal of Political Research, 3, 147-171. http://dx.doi.org/10.1111/j.1475-6765.1975.tb00521.x

Mason, E. (1957). Economic Concentration and the Monopoly Problem. Cambridge, MA: Harvard University Press.

Morgan-Thomas, A., \& Jones, M. V. (2009). Post-entry Internationalization Dynamics: Differences between SME's in the Development Speed of their International Sales. International Small Business Journal, 27(1), 71-97. http://dx.doi.org/10.1177/0266242608098347

Mosakowski, E., \& Earley, P. C. (2000). A Selective Review of Time Assumptions in Strategy Research. Academy of Management Review, 15(4), 796-812. http://dx.doi.org/10.5465/AMR.2000.3707728

Musteen, M., Francis, J., \& Datta, D. K. (2010). The influence of international networks on internationalization speed and performance: A study of Czech SMEs. Journal of World Business, 45(3), 197-205. http://dx.doi.org/10.1016/j.jwb.2009.12.003

Nelson, R. R., \& Winter, S. G. (1982). An Evolutionary Theory of Economic Change. Cambridge, MA: The Belknap Press of Harvard University Press.

Neter, J., Kutner, M., \& Nachtsheim, C. (1996). Applied Linear Statistical Models. Chicago: Irwin.

Padmanabhan, P., \& Cho, K. R. (1999). Decision Specific Experience in Foreign Ownership and Establishment Strategies: Evidence from Japanese Firms. Journal of International Business Studies, 30(1), 25-43. http://dx.doi.org/10.1057/palgrave.jibs.8490059

Porac, J. F., \& Rosa, J. A. (1996). Rivarity, Industry Models, and the Cognitive Embeddedness of the Comparable Firm. Advances in Strategic Management, 13, 363-388.

Prashantham, S., \& Young, S. (2011). Post-Entry Speed of International New Ventures. Entrepreneurship Theory and Practice, 35(2), 275-292. http://dx.doi.org/10.1111/j.1540-6520.2009.00360.x

Shaver, J. M., Mitchell, W., \& Yeung, B. (1997). The effect of Own-firm and Other-firm Experience on Foreign Direct Investment Survival in the United States, 1987-92. Strategic Management Journal, 18(10), 811-824. 
http://dx.doi.org/10.1002/(SICI)1097-0266(199711)18:10<811::AID-SMJ924>3.0.CO;2-8

Smith, K. G., Grimm, C. M., Gannon, M. J., \& Chen, M. J. (1994). Organizational Information-Processing, Competitive Responses, and Performance in the United-States Domestic Airline Industry. Academy of Management Journal, 34(1), 60-85.

Stalk, G., \& Hout, T. M. (1990). Competing against Time: How Time-based Competition is Reshaping Global Market. New York: Free Press.

Tirole, J. (1988). The Theory of Industrial Organization. Cambridge, MA: MIT Press. 